\title{
INSTITUTIONAL CAPACITY BUILDING OF STUDENT AFFAIRS AT UNIVERSITY OF BRAWIJAYA
}

\author{
Nugraha Setya, Sumartono, Amin Fadillah \\ Master of Art and Higher Education, Faculty of Administrative Science, \\ University of Brawijaya, Indonesia \\ *E-mail: setyanugraha88@gmail.com
}

\begin{abstract}
This study aims to identify and describe an existing condition and institutional capacity building performance of student affairs at University of Brawijaya. This was qualitative descriptive research. The data was collected by obeservation, interview and documentation. The result shows that the institutional existing condition of student affairs at University of Brawijaya has improved at several areas, but it still leaves a trouble at leadership condition and coordinatioan among stakeholder. On the other hand, a strategy to perform capacity building was through six indicators: human resources, organizational structure, working mechanism, organizational culture, budgeting system, and leadership. Institutional capacity building performance of student affairs at University of Brawijaya has been succesfully done, but it still leaves problem of leadership and cultural organization.
\end{abstract}

\section{KEY WORDS}

Institutional capacity building, student affairs, institution.

Higher education is a key of civilization state being developed in this globalization era as at university human resources are educated to apply their ability in the community. Today's phenomenon is almost all of public service institutions experience a weakness in institutional reinforcement process which causes service process becomes low, for instance, reinforcement process and institutional at Higher Education.

Capacity building is term known in understanding institutional development. UNDP and Canadian International Development Agency (CIDA) in Milen (2016:15) stated that capacity building is a process by which individual, group, organization, institution, and community improve their ability to: (a) result in performance of main duties and functions, solve problem, formulate and realize arranged goal achievemnt, and (b) understand and fulfil improvement needs in a wider context and sutainable way.

Capacity building is a strategic formula to analyze how assessment and strategy for a human or organization potential. University of Brawijaya has Organizational Structures and Working Procedures (OTK) as stipulated in the Regulation of Minister of Research, Technology and Higher Education no.4/2016. Type of institutional structure and it functions are clearly explained in the OTK. In term of student affairs development, the most responsible institution is student affairs division and student organizations.

Capacity building in this institutional dimention is a strategy to enhance goal achieved. Institution's goal is surely stipulated in the Vision, Mission, Purpose, and Workplan, therefore capacity building is required to enhance performance achievement which is expected maximal. Grindle (1997: 1-28) stated that if capacity building is a set of strategy aims to enhance efficiency, effectiveness and responsiveness, thus it has to focuse on the three dimesions, namely (1) human resources building, (2) organizational reinforcement, and (3) institutional reformation. They are an analysis tool to find problems or strategy used by organization. Dimension choosen to make this study more spesific is organizational reinforcement.

Problems often come to the institutional of students affairs are the lack of coordination among stakeholder and weak leadership. The next problem is leadership issue at the institutional of student affairs. Capacity building aims to create effectiveness and institutional 
performance enhancement. Student affairs division of University of Brawijaya has ever been assessed on its performance and achivement.

Indonesia's higher education ranking carried out by Directorate General of Higher Education (DIKTI) uses several indicators: human resources quality, management, student activiy, and research and publication. Of those four indicators, the lowest score is 2.0 held by students activity, less with the quality of human resources by 3.68 , management quality by 3.8 , and research and publication quality by 2.5 . Therefore, problem statement discovered in this study is how: (1) to analyze institutional condition of student affairs at University of Brawijaya and (2) institutional capacity building of student affairs at University of Brawijaya and supporting and barrier factors.

This paper aims to describe and analyze: (1) institutional condition of student affairs at University of Brawijaya, (2) institutional capacity building performance of student affairs at University of Brawijaya, and (3) its supporting and barrier factors.

\section{METHODS OF RESEARCH}

This was descriptive qualitative research focusing on (1) Institutional Condition of Student Affairs at University of Brawijaya; (2) Institutional Capacity Building performance of student affairs at University of Brawijaya with sub focus: (a) Human resources, (b) Organizational structure, (c) working mechanism, (d) organizational culture, (e) budgeting system, (f) leadership; and (3) Supporting and Barrier Factors of institutional capacity building of student affairs at University of Brawijaya.

This study was conducted at University of Brawijaya, while the research site are rectorate and the area of student organization at University of Brawijaya. Types of data are primary and secondary data and data resources are a) informant; b) circumstances/location; c) document. The data were collected through interview, observation, and documentation (Sugiyono, 205:62). Research instrument was the researchers itself who directly went to the field to collect data and mostly relied on human instrument. The data was analyzed using Interactive Model of Analysis consisting of: Data condensation, Data display, Conclusion Drawing/verification (Miles, Huberman and Saldana, 2014:12).

\section{RESULTS AND DISCUSSION}

Institutional existing condition of student affairs at University of Brawijaya illustrates a lot of unique results and findings. There is strength and weakness internally and opportunity and threat externally. The internal strength is that the organization leader has brought a fundamental framework for its members to achieve several quality improvements during 2006-2014 for a better performance in the future. For instance, well-trained and the goodwill of human resources are able to provide service for students. Acievement of University of Brawijaya at national-scale competition increases. On the other hand, the lack of institutional condition of student affairs is the leader itself who can not be a role model yet. Personal problem making leader does not have ability to influence his/her staff.

Opportunity of institutional existing condition of student affairs at University of Brawijaya are among others support from Indonesian Ministry of Research, Technology and Higher Education (Kemenristekdikti) appreciating an increase of student activity ranking from 3 to 2 in the national competition. Meanwhile, a threat to institutional existing condition of student affairs at University of Brawijaya is a matter of support from almuni which is getting low. It is proven by online petition proposed to the head of student affairs of University of Brawijaya.

In term of performing individual capacity building, competence level or individual capacity can be measured through Gross' concept quoted by Richard (1984:55) stating that competence which has to be owned by apparatus in performing duties and functions of government and development is as follow:

1. Knowledge. An understanding owned by Human Resources at institutional of student affairs is a competence field handled during working or performing activity. 
For instance, scholarship support staff has been trained to be more humanists and discovering intricacy of scholarsip information for students as well as organizing the mechanism of the scholarship.

2. Managerial Competence. Sudents as a stakeholder are educated about this competence, but education supports staff also accepts this shortly during outbond training. As a result, managerial competence of students and education support staff to provide service and activity quality becomes more effective.

3. Purpose and Norms and Ethics. Norms and ethics owned by the human resources should be nurtured from the underlying culture of student affairs. For that matter, the previous leaders of the organization has internalized beneficial norms and ethics to all members of the student affairs in order to create the necessary atmosphere to quality performance. Capacity building performance with indicator of human resources was carried out at several trainings both to the education support staff and students, thus creating nationally-proud service and students' affairs activity.

An effective organizational structure has been succesfully created as it is proven by secondary data of management assessment achievement of bureaucratic reform structural which get good value from Kemenristekdikti. Therefore, organizational structure in form of better improvement and is fit to the referral of Kemenristekdikti has been performed, despite in the performance managerial it needs an adaptation and the total of work load increases. As a result it needs one-year adaptation before accustoming to the new organizational structure of OTK.

The existing institutional procedures and rules are heavily influenced by other factors such as leadership. Consequently, norms that has to be obeyed by all the stakeholders can not be implemented maximally because of a sudden change in policy and sometimes violate the procedures that have been made, yet conditions in the field happened the opposite. Performance standards, norms, and agreed procedures are often not well executed. There are many factors why procedure does not run smoothly such as time determination, student organization condition, and leadership which often makes a policy changes, so that a fullydetermined and must be complied procedure is often violated.

Firmansyah (2012:21) precisely displayed a concept on how to create an effective organization which is started from good cultural organization. Student affairs staff stated that student or student organizations equally aware that the attitude of mutual appreciation and giving social awareness to the job assignements performed by students affairs is more tactical nature. Therefore, institutional of student affairs gives more effort compared to other sector institutions, if it doesn not have the nature of social awareness, then the effective performance result is not easily perceived.

According to the findings, University of Brawijaya can be said as successfully bringing good achievement to the institutional of students' affairs. However, the Rector of University of Brawijaya feels that correction, support and budgeting apreciation for institutional of student affairs needs more attention. Therefore, it needs more budget allocation and the one chosen is increasing support for international competition. It is a preliminary support for goo institutional capacity building of student affairs.

Ken Blanchard's idea quoted by Marcelene caroselli (2000: 9) states that the key of today's leadership is "influence" rather than "power", he further says that leaders know how to influence people and persuade them to demand high jobs. Yet what happened in University of Brawijaya, the leader of student affairs institutional turned out to be interpreting that the leader was in power not influence. This is evident from the arbitrariness of issuing policies so accpeting a case of protest by alumni in social media. It can be said that the institutional leader of this student affairs failed to give effect, but succesffully managed to show that he is in charge.

Supporting factors of institutional capacity building of student affairs are alumni support and appreciation got by government for the quality performance of student activities. The Ministry's support is given in the form of attention to the development of student resource potentials. So that the increase of graduate competency as the goal of student organization can be achieved effectively. 
The inhibiting factor of institutional capacity building of student affairs is the limited budget which causes students not fully supported to compete. The reason for this budget is complicated, because posture and budget planning have been designed since the beginning of the University's budget planning. While the needs of student activities and competitions are always sudden and difficult to predict. Another factor is conducive leadership. Leaders are the determinants of institutional capacity building. That is not happened at university of Brawijaya since the is no ease in the process of leadership and the way organization goes. At the end, leader is the one who precisely prevert the institutional capacity building instead of encourage it.

\section{CONCLUSION}

With regard to the findings, the institutional condition of student affairs at University of Brawijaya is considered conducive; yet, the there are some leadership factors that may lead to the downgrade of the internal institutional capacity building.

Institutional capacity building of student affairs aims to realize an effective institution has been performed well. An effective institutional has six indicators:

Human resources. Capacity building performance with indicator of human resources was carried out at several trainings both to the education support staff and students, thus having been created nationally-proud service and students' affairs activity.

Organizational Structure. After reformation process, organizational and methodological structure of University of Brawijaya generally and student affairs particularly follow referral from Kemenristekdikti to achieve an effective institutional.

Working Mechanism. Key Performance Indicator (KPI) is applied in the mechanism of student affairs institutional despite does not perform maximally yet. Therefore, performance assessment can be more measurable over the target.

Organizational Culture. Organizational culture which has been apperaing since previous periode is continuously performed by stakeholder, however leadership factor can not support yet more positive organizational culture improvement.

Budgeting System. Supporting funding to increase international achievement and establishing of Student Affairs Information System (SIKMA) is the result of institutional capacity building process of student affairs.

Leadership. Personal problem causes institutional capacity building of student affairs with leadership indicator can not be found. Leader who should encourage capacity building can not be performed yet since the communication failure.

Contributing factors are organizational culture and support from government that has to be maintained consistently. Barrier factors of institutional capacity building of student affairs at University of Brawijaya is the leadership style which is less satisfactory, budgeting support that which has less support, and support from alumni which put less believe on the student affairs leadership.

\section{REFERENCES}

1. Caroselli, M. 2000. Leadership Skill for Managers. New York: McGraw-Hill.

2. Firmansyah, M.A. 2012. Budaya organisasi terhadap efektifitas Organisasi. Ubaya.

3. Grindle, M.S. \& Hilderbrand (Ed). 1997. Getting Good Government: Capacity Building in The Public Sector Of Developing Countries, Boston.

4. Keban, Y.T. 2000. Good Governance dan Capacity Building Sebagai Indikator Utama Dan Fokus Penilaian. Jurnal Perencanaan Pembangunan, Jakarta.

5. Milen. 2006. Capacity Building: Meningkatkan Kinerja Sektor Publik. Yogyakarta: Pembaruan.

6. Miles, M.B, Huberman, A.M., and Saldana, J. 2014. Qualitative Data Analysis, a Methods Sourcebook, Third Edition. Sage Publications, Inc.

7. Moleong J.R. 2004. Metodologi Penelitian Kualitatif. P.T. Remaja Rosdakarya. Bandung.

8. Steers, R.M. 1984. Efektivitas Organisasi, Erlangga, Jakarta. 